\title{
Recovery of low temperature heat in oil mills
}

\section{Patrick CARRÉ}

\author{
CREOL, \\ 11 rue G. Monge, \\ 33600 Pessac, \\ France \\ $<$ carre@cetiom.fr>
}

Article received 21 September 2012

Accepted 29 September 2012

\begin{abstract}
Energy consumption in oil mills is a major item of costs and a sensitive point in the production of biofuels. To improve their performance, industrials can recover lowtemperature heat thanks to a new technology of heat exchangers suitable for treating granular solid materials. Information about the energy requirements of the rapeseed crushing being not readily available, the article gives a detailed assessment of consumption items (per ton of seed: 263 MJ for preparation operations and $284 \mathrm{MJ}$ for solvent extraction). These exchangers used as pre-conditioners saves about $55 \mathrm{MJ} . \mathrm{t}^{-1}$ of heat by use of steam condensates. We could go further in use of these devices on the one hand to recover heat from press cake and meal, and secondly to use recovered energy to dry and warm up the seeds before pre-pressing. In this configuration, the energy savings could reach $38 \%$ of current needs.
\end{abstract}

Key words: oilseeds, crushing, energy saving, heat transfer, rapeseed, drying

specific heats of seeds, oilcakes, meal and oil. The available values are relatively rare, often old and vary quite widely. Table 1 shows some thermal values from the literature.

Values used in this study : $1.9 \mathrm{~kJ} .{ }^{\circ} \mathrm{C}^{-1} \cdot \mathrm{kg}^{-1}$ for seeds and meals, $2 \mathrm{~kJ} .{ }^{\circ} \mathrm{C}^{-1} \cdot \mathrm{kg}^{-1}$ for oil, $2.27 \mathrm{~kJ} / \mathrm{kg}$ for hexane, latent heat of vaporization of hexane: $328 \mathrm{~kJ} / \mathrm{kg}$, boiling point of hexane $69{ }^{\circ} \mathrm{C}$ (Linde, 2009). Characteristics of seeds and meals: in this study, seeds were considered having a water content of $7.8 \%$ and an oil content of $45.0 \%$. These values represent the average outcome of CETIOM's investigation "rapeseed crop quality" between 2007-2011 (Garnon, 2011). Meal, according to the last issue of the survey of the French organization for oilseeds (2011) have average water content of $11.3 \%$ and an oil content of $2.7 \%$ $( \pm 0.5)$ in the year 2011 (Peyronnet and Dauguet, 2012). It was considered for the press cake an oil content of $21 \%$. Products flows and material balance are shown in the figure 1.

\section{Thermal energy consumption in crushing industry}

The needs assessment of the theoretical heat required for different stages of crushing must take into account the process was divided into two main parts: mechanical extraction and solvent extraction.

\section{Mechanical extraction}

\section{Thermal conditioning}

This step is not mandatory but is applied in most crushing units. Seeds are preheated prior to flaking at temperature of approximately $60^{\circ} \mathrm{C}$ without significant change in water content. This preheating improves the plasticity of seeds and improves the formation of the flakes. Its main difficulty arises from the low thermal conductivity of rapeseed. According to Timbers (1975), the thermal conductivity of rapeseeds is in the range 0.10 and $0.15 \mathrm{~W} \mathrm{~m}^{-1} .{ }^{\circ} \mathrm{C}^{-1}$. In practice, this means that the seed acts as an insulating material. For comparison, these values are between the thermal conductivity of plywood $\left(0.11 \mathrm{~W} . \mathrm{m}^{-1} \cdot{ }^{\circ} \mathrm{C}^{-1}\right)$ and pine wood $\left(0.15\right.$ W.m $\left.\mathrm{m}^{-1} \cdot \mathrm{C}^{-1}\right)$. Conduction alone cannot heat a mass resting on a heating surface. It is therefore necessary to force convection by vigorous shaking of the seeds and a fairly large exchange surface is required to allow the heat exchange. For example, the figure 2 relates the change in temperature measured by a thermocouple in a layer of $10 \mathrm{~mm}$

To cite this article: Carré P. Recovery of low temperature heat in oil mills. OCL 2012; 19(6): 324-331. doi : 10.1684/ocl.2012.0482 
Table 1. Some values about specific heats of the products handled in oil meals.

\begin{tabular}{|c|c|c|c|}
\hline Product & Specific heat $\left(\mathrm{kJ} .{ }^{\circ} \mathrm{C}^{-1} \cdot \mathrm{kg}^{-1}\right)$ & Comments & Source \\
\hline Flakes (rapeseed) & 2,5 & \multirow{2}{*}{$\begin{array}{l}\text { Values likely to be overestimated } \\
\text { but taken in account at industrial level }\end{array}$} & \multirow{2}{*}{$\begin{array}{l}\text { (Laisney, 1984) } \\
\text { (Laisney, } 1984\end{array}$} \\
\hline Oils & 2,3 & & \\
\hline \multirow{4}{*}{ Soybeans } & $1,20+0,042 \cdot H+0,005 \cdot T$ & $\begin{array}{l}\mathrm{C}=1,83 \\
\text { Water: } 8 \%, \mathrm{~T}^{\circ}: 60{ }^{\circ} \mathrm{C}\end{array}$ & $\begin{array}{l}\text { (Berthon, 1977) } \\
\text { (Berthon, 1977) }\end{array}$ \\
\hline & $1,444+0,059 . \mathrm{H}$ & $\begin{array}{l}\mathrm{C}=1,91 \\
\text { Water: } 8 \%, \mathrm{~T}^{\circ}: 42{ }^{\circ} \mathrm{C}\end{array}$ & $\begin{array}{l}\text { (Deshpande \& Satish, 1999) } \\
\text { Deshpande \& Satish, 1999) }\end{array}$ \\
\hline & $1,593+0,0259 . \mathrm{H}$ & $\begin{array}{l}C=1,81 \\
\text { Water: } 8 \%, T^{\circ}: \text { not specified }\end{array}$ & $\begin{array}{l}\text { (Alam \& Shove, 1973) } \\
\text { (Alam \& Shove, 1973) }\end{array}$ \\
\hline & $\begin{array}{l}-101,10,12 \cdot \mathrm{H}-0,00013 \\
\mathrm{H}^{2}+0,63 \cdot \mathrm{T}-0,00097 \\
\mathrm{~T}^{2}-0.00032 \cdot \mathrm{HT}\end{array}$ & $\begin{array}{l}\mathrm{T}^{\circ} \text { in } \mathrm{K} \\
1.90 \text { at } 8 \% \text { water and } 60{ }^{\circ} \mathrm{C}\end{array}$ & $\begin{array}{l}\text { (Aviara, et al., 2011) } \\
\text { Aviara, et al., 2011) }\end{array}$ \\
\hline \multirow{5}{*}{ Rapeseed } & 2,68 & Water: $11 \%$ & $\begin{array}{l}\text { (Srours, 1982) } \\
\text { (Srours, 1982) }\end{array}$ \\
\hline & $1,287+0,067 . \mathrm{H}$ & $\begin{array}{l}\text { 1,82 at water: } 8 \% \\
\text { Variable/cultivars } \pm 0,13 \text { ) }\end{array}$ & $\begin{array}{l}\text { (Timbers, 1975) } \\
\text { (Timbers, 1975) }\end{array}$ \\
\hline & $1,356+0,032 . \mathrm{H}$ & $\begin{array}{l}\mathrm{T}^{\circ}: 19{ }^{\circ} \mathrm{C} \\
1.61 \text { at } 8 \% \text { water }\end{array}$ & $\begin{array}{l}\text { (Moysey, et al., 1977) } \\
\text { (Moysey, et al., 1977) }\end{array}$ \\
\hline & $1.265+0.03 . \mathrm{H}+0.00575 . \mathrm{T}$ & 1.85 at water: $8 \%, \mathrm{~T}^{\circ}: 60^{\circ} \mathrm{C}$ & $\begin{array}{l}\text { (Muir \& Sinha, 1986) } \\
\text { (Muir \& Sinha, 1986) }\end{array}$ \\
\hline & 2,10 à 3,12 & (article in Turkish language) & $\begin{array}{l}\text { (Kocabiyik \& Tezer, 2007) } \\
\text { (Kocabiyik \& Tezer, 2007) }\end{array}$ \\
\hline Sunflower seeds & $5,57 \pm 1,2(2 s)$ & Water: $9.7 \% \mathrm{~T}^{\circ}: 80^{\circ} \mathrm{C}$. & $\begin{array}{l}\text { (llori, et al., 2011) } \\
\text { (llori, et al., 2011) }\end{array}$ \\
\hline Rapeseed oil & 1,96 & $\mathrm{~T}^{\circ}: 20-30^{\circ} \mathrm{C}$ & \multirow{2}{*}{$\begin{array}{l}\text { (Joly, 1982) } \\
\text { (Joly, 1982) }\end{array}$} \\
\hline Soybean oil & 1,75 + 0,0029.T & $2,04 \mathrm{~T}^{\circ}: 100{ }^{\circ} \mathrm{C}$ & \\
\hline
\end{tabular}

$\mathrm{H}$ : water content $\%$; $\mathrm{T}$ : temperature $\left({ }^{\circ} \mathrm{C}\right)$

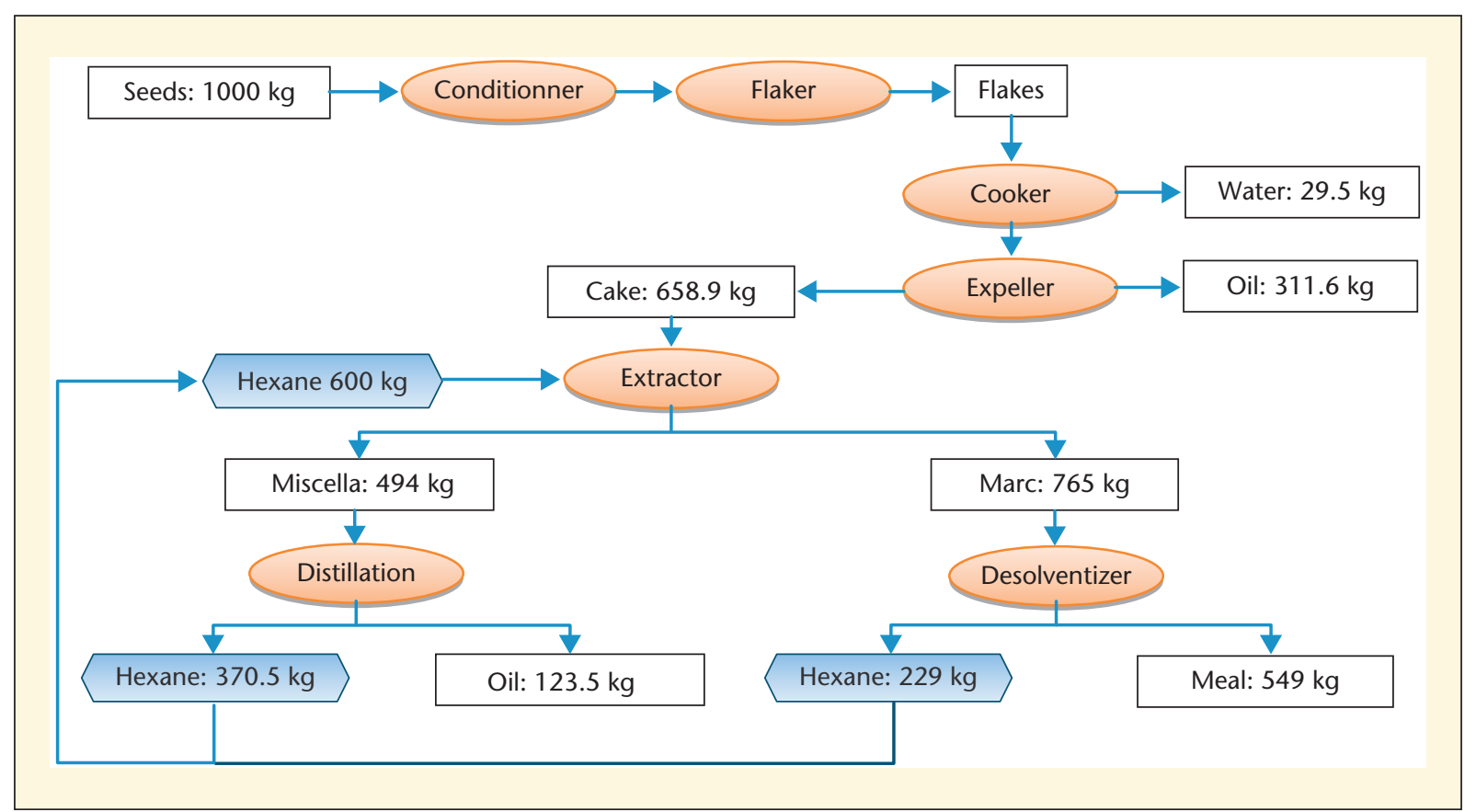

Figure 1. Mass flows during rapeseed processing. 


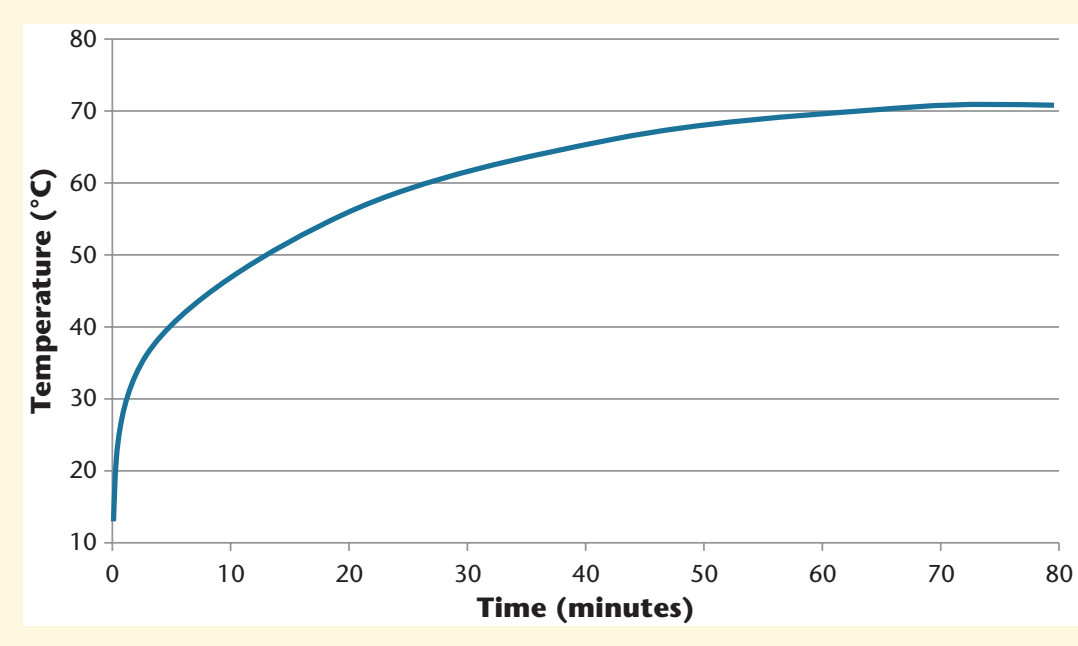

Figure 2. Evolution of the temperature in the center of a $10 \mathrm{~mm}$ layer of cold rapeseed between two masses of rapeseed at $72{ }^{\circ} \mathrm{C}$ (CREOL, unpublished data).

rapeseed initially at $15^{\circ} \mathrm{C}$ between two layers of seeds at $72{ }^{\circ} \mathrm{C}$. It shows that half an hour is necessary to reach $60{ }^{\circ} \mathrm{C}$ at $5 \mathrm{~mm}$ from the warm seeds.

An indirect consequence of this difficulty is the need to keep the seeds for a relatively long time in conditioners and because it is accompanied by vigorous stirring, the mixing is an important cause of residence time dispersion.

\section{Flaking and conveying}

Flaking by itself does not significantly modify the temperature of the material, however, transport between the conditioner, flakers and cookers allows significant heat loss which varies according to the length of the circuits and their ability to dissipate heat. The magnitude of these losses was estimated to $5{ }^{\circ} \mathrm{C}$.

\section{Cooking}

Cooking flakes improves the capacity of presses to extract the oil and produce oilcakes with favorable characteristics to subsequent extraction steps. The three main effects of cooking are: 1) a reduction in the viscosity of oil allowing it to flow better through the cake (Darcy's law), 2) a coagulation of interfacial proteins leading to the destabilization of oilbodies to increase oil availability and 3) a more or less important drying action resulting in a final water content of between 4 and $6 \%$ in flakes. Water acts as a plasticizer in the cake, reducing its ability to oppose the force of screws which leads to less important pressures in wet conditions and a weak deoiling performance. A loss of $29.5 \mathrm{~kg}$ of water per ton of crushed seeds was considered in the case study (7.9\% to $5.0 \%$ water in flakes).

\section{Expelling}

The principle of mechanical extraction is to maintain the solid matrix in a cage designed to let liquid flow and strong enough to resist to high mechanical force exerted by a rotating screw pushing the solid across constantly reduced volumes. The mechanical work of the screw is degraded into heat which raises the temperature of the cake and to a lesser extent the one of the oil.

\section{Clarification of the press oil}

Before being stored, the oil should be filtered or clarified by centrifuge decanting. These treatments do not require supplementary heating of the oil.

\section{Cake Granulation}

Granulation is not systematic, but rapeseed cake produced by high-speed high-capacity screw presses often exhibits characteristics that are not optimal for solvent extraction, especially when said extractors are not compartmentalized and allow horizontal circulation of miscellas when its vertical percolation is slow. Indeed, for making an effective countercurrent extraction, the solid material must have two qualities: good extractability of oil and a homogeneous and relatively fast percolation of liquid through thick layer. The extractability assumes that the solvent can dissolve the oil enclosed inside the cake particles. Two obstacles may occur: a defect of milling corresponding to a lack of cells disruption and a defect of permeability corresponding to the smoothing and compacting of the surface by the press. Well controlled granulation produces pellets with favorable solvent absorption and offer perfect percolation characteristics. This effect is not guaranteed because granulation can also reduce the permeability of the cake to hexane. In practice, it is rather for its effect on the regularity of the percolation that granulation was adopted. Another benefit is an improvement in cake density that has the effect of improving the capacity of extractors.

\section{Pellets cooling}

The pellets come out at a temperature in the range 105 and $115{ }^{\circ} \mathrm{C}$. They cannot be sent directly to the extraction because their high temperature generates a risk of vaporization of the solvent. Cooling is done by blowing air through the cake. The goal is to reduce the temperature at the higher level compatible with the safety of the plant. For our study, we considered $80^{\circ} \mathrm{C}$.

\section{Countercurrent extraction and solvent regeneration}

Pellets, cake, collets or flakes are extracted by percolation of hexane in countercurrent extractors. The extraction temperature is a compromise between the necessity to take advantage of the positive effect of heat on extraction rate and the rise of solvent losses near to boiling point (Baumeler, et al., 2010). In practice, this temperature can vary from 45 to $60^{\circ} \mathrm{C}$. A value of $55^{\circ} \mathrm{C}$ was used in the assessments of this study.

The solvent enters in the extractor at a temperature close to $40{ }^{\circ} \mathrm{C}$. A concentration of oil in miscella of $25 \%$ and retention of hexane by the marc of $30 \%$ were considered in our assessments. This requires the use of about $600 \mathrm{~kg}$ of solvent per ton of crushed seeds. In reality, the hexane content of the marc is dependent on the type of extractor and quality of the cake (granulation). For thick layer extractors (3 $\mathrm{m}$ ) with non-granulated cakes, impregnations may exceed $35 \%$, while values below $25 \%$ can be observed in thin layer extractors $(<1 \mathrm{~m})$ on pelletized cakes. Regarding the concentration of miscellas, it is possible to achieve much higher concentrations. Laisney in 'L'Huilerie Moderne" shows concentrations of 38\% (Laisney, 1984). 
Table 2. Summary of the heat consuming operations in rapeseed crushing (per ton of seeds).

\begin{tabular}{|c|c|c|c|c|}
\hline Step & Material & Change & Heat required (MJ.t $\left.{ }^{-1}\right)$ & Steam consumption $\left(\mathrm{MJ} . \mathrm{t}^{-1}\right)$ \\
\hline Conditioning & Seeds & $\mathrm{T}^{\circ}: 15 \rightarrow 60^{\circ} \mathrm{C}$ & 78 & 36.6 \\
\hline \multirow{3}{*}{ Cooking } & \multirow{2}{*}{ Flakes } & $\mathrm{T}^{\circ}: 55 \rightarrow 105^{\circ} \mathrm{C}$ & 110 & 53.4 \\
\hline & & Vaporization of $30 \mathrm{~kg}$ of water & 66 & 32.2 \\
\hline & Air (dry) for drying & $\mathrm{T}^{\circ}: 20 \rightarrow 100^{\circ} \mathrm{C}$ & 8 & 3.9 \\
\hline Total preparation & & & 263 & 126 \\
\hline \multirow{5}{*}{ Desolventization } & Meal & $\mathrm{T}^{\circ}: 55 \rightarrow 105^{\circ} \mathrm{C}$ & 52 & 26.1 \\
\hline & \multirow{2}{*}{ hexane } & $\mathrm{T}^{\circ}: 55 \rightarrow 69^{\circ} \mathrm{C}$ & 8 & 3.9 \\
\hline & & Vaporization & 75 & 37.6 \\
\hline & \multirow{2}{*}{ Steam } & Sparged & 77 & 27.5 \\
\hline & & Condensed & 38 & 13.5 \\
\hline \multirow{3}{*}{ Distillation } & Miscella & $\mathrm{T}^{\circ}: 55 \rightarrow 69^{\circ} \mathrm{C}$ & 8 & 2.7 \\
\hline & Oil & $\mathrm{T}^{\circ}: 69 \rightarrow 110^{\circ} \mathrm{C}$ & 10 & 3.6 \\
\hline & Hexane & Vaporization & 122 & 58.9 \\
\hline \multicolumn{3}{|c|}{ Enthalpy supplied by the gas from the DT } & -104 & -48.9 \\
\hline \multicolumn{3}{|l|}{ Total extraction } & 284 & 125 \\
\hline \multicolumn{3}{|l|}{ Losses (5\%) } & 27 & 12.5 \\
\hline \multicolumn{3}{|c|}{ Total preparation + extraction } & 574 & 264 \\
\hline
\end{tabular}

\section{Desolvation of marc}

After extraction, the solvent from which the marc is impregnated must be removed by indirect heating and direct steam injection. Indirect heating is obtained by forcing the material to contact a tray heated by steam which is condensed in a double jacket located under the tray. Direct steam is injected countercurrently in the lower trays of desolventizer. Direct steam has two effects: it brings large amount of heat by condensation when it encounter the relatively cold marc and it decreases the concentration of hexane vapors in desolventizer atmosphere, a desaturation allowing the final desorption of the solvent in the bottom trays. The amount of direct steam to be used is modulated to reach a temperature of $70{ }^{\circ} \mathrm{C}$ in the vapors leaving the desolventizer (Schumacher, 1983). According to Schumacher, $0.12 \mathrm{~kg}$ of steam per $\mathrm{kg}$ of hexane is required to reach this temperature. Desolventizers technology has evolved over time; major changes have focused on the management of predesolventization and steam injection. According to the devices designs, we can observe a certain disparity in the mass of condensed water in the meal. Generally, there is an excess of water in the meal requiring a drying treatment downstream. In some new desolventizers, direct steam condensation is re- duced by separating the vapors stemming from the desolventizer of the pre-desolventizing part of the device. One of the reasons that led to this evolution is the necessity to reduce the loss of protein solubility due to the wet cooking. Nevertheless, there are still many desolventizers with just one steam outlet and, in many plants; this operation is a bottleneck that requires the operator to use the equipment in sub-optimal conditions in order to cope with the constraint on the solvent conservation. In consequence, the real consumption of steam for the meal desolventization may represent higher figures than given in table 3. As explained above, the largest cause of over-consumption is due to condensation of direct steam leading to an excess of water content in the meal. The enthalpy of vaporization of condensed steam is lost during the drying step. In the present study, it was considered that we just consumed the amount of direct steam required to reach $11.5 \%$ of water in meal.

\section{Miscella distillation and heat recovery from the desolventizer}

The gases exiting the desolventizer pass through an exchange column to recover the condensation heat and evaporate a portion of the miscella. This exchange, according to Anderson (1989), allows ensuring that $75 \%$ of the heat necessary for distillation of the miscella is provided by the vapors leaving the DT. On the basis of our case study values, distillation requires $139 \mathrm{MJ} / \mathrm{t}$ of seeds from which $104 \mathrm{MJ}$ are supplied by the vapors of the desolventizer. Distillation uses direct steam in ejectors to generate some vacuum and to help stripping the solvent residues but these flows are partially recovered and it was considered that they were included in the residual $25 \%$.

The real values vary according to the amount of steam condensed in desoIventizer and the performance of the heat recovery for the miscella pre-concentration. As explained in the introduction, the industrial data are not accessible but the presented figures were assessed by careful recoupment of available information and use of conservative hypothesis. They can be regarded as reasonably accurate valuation of the real consumptions of the most efficient oil mills given that on average, the actual values are more frequently at higher levels (figure 3).

\section{Production of heat by condensation of high pressure steam and low-temperature heat}

In oil mills, the main thermal vector in use is 10 bar saturated steam. The heat transfer is made when steam is con- 


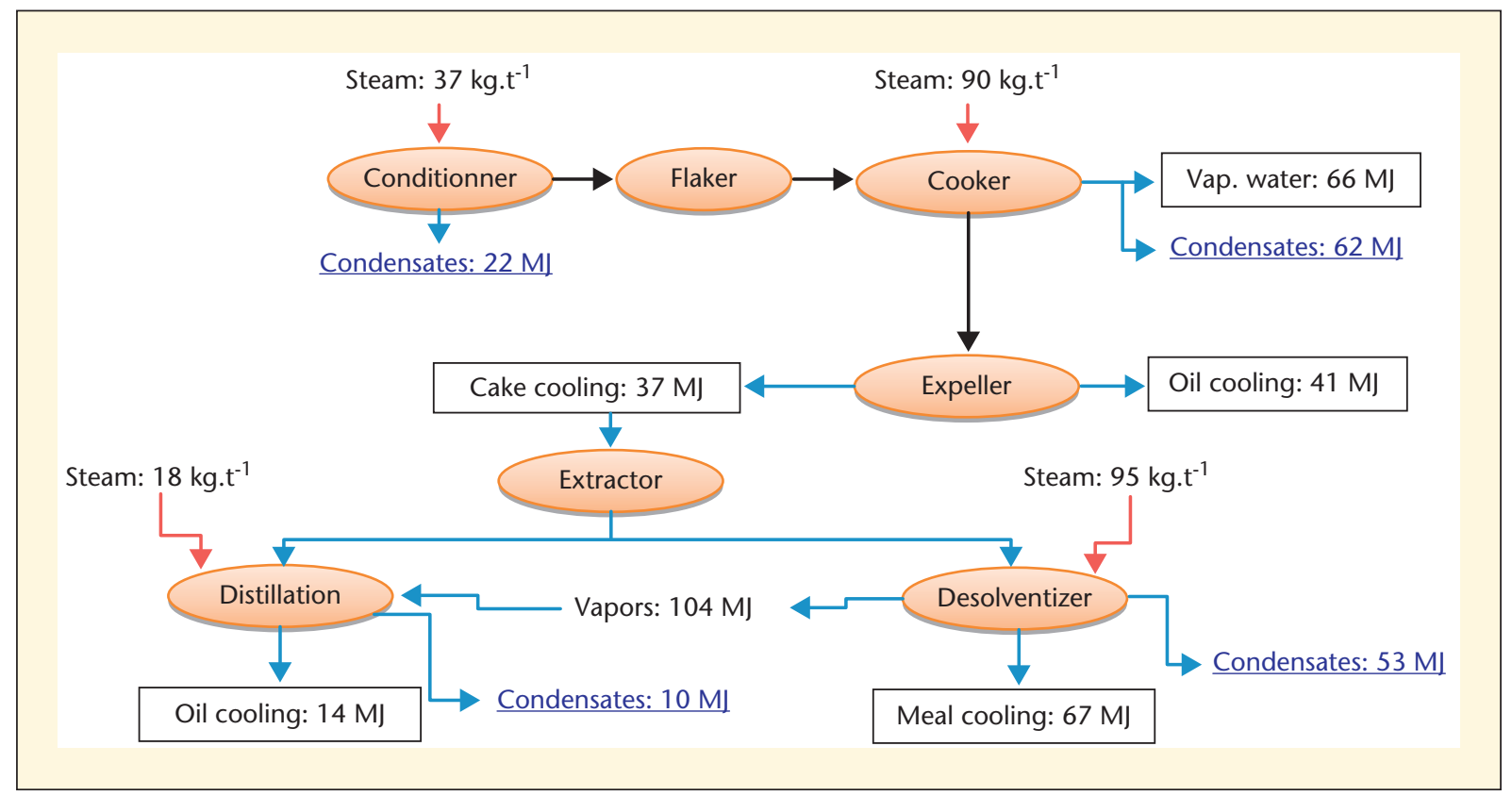

Figure 3. Streams of recoverable heat in processing $1 \mathrm{t}$ of seeds.

densed in one side of the exchange surface to yield the water enthalpy of vaporization which is transferred to the heated material by conduction across the steel wall of the exchanger. Since the thermal conductivity of the solid materials is weak, a high differential of temperature is required to obtain satisfactory performance. On the side of steam, the temperature is the one of saturated water presented in table 2. When the condensates are purged, they go to a lower pressure which leads to partial revaporization. According to the data in table 3, around $70 \%$ of steam is used indirectly in heat exchangers. The residual enthalpy of condensates depends on the initial pressure so we considered an average value of 6 bars with $0.7 \mathrm{MJ} . \mathrm{kg}^{-1}$ to be returned toward the boiler at 0 bars and $80{ }^{\circ} \mathrm{C}$ $\left(0.33 \mathrm{MJ} . \mathrm{kg}^{-1}\right)$. Each $\mathrm{kg}$ of condensates can deliver $0.37 \mathrm{MJ} . \mathrm{kg}^{-1}$. Considering that we could replace the pre-condi- tioner by a low temperature heat exchanger, we would subtract the condensates previously produced by this device from the $185 \mathrm{~kg}$ of condensates of our valuation. With $150 \mathrm{~kg}$ of

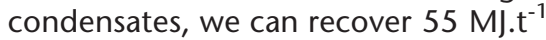
of seeds, i.e. $9.6 \%$ of the total needs of heat of the oil mill.

\section{Other potential sources of low temperature heat}

Oil from mechanical extraction and oil from solvent extraction go out of the system at temperatures close to $100{ }^{\circ} \mathrm{C}$. Returning them to $35{ }^{\circ} \mathrm{C}$ could allow recovering $55 \mathrm{MJ} . \mathrm{t}^{-1}$ of crushed seeds.

Water exiting the cooker could be condensed to recover $66 \mathrm{MJ} \cdot \mathrm{t}^{-1}$.

Cooling the cake before extraction from $110{ }^{\circ} \mathrm{C}$ to $80{ }^{\circ} \mathrm{C}$ could supply $37 \mathrm{MJ} . \mathrm{t}^{-1}$.

Cooling the meal after desolventization could supply $67 \mathrm{MJ} \cdot \mathrm{t}^{-1}$.
In total $225 \mathrm{MJ} . \mathrm{t}^{-1}$ could be saved provided that efficient heat exchanger could enable this recovery and that one has the possibility to use the recovered heat with its low temperature (figure 3).

\section{Opportunities for recovery of low temperature heat}

Thermal conditioning of seeds before flaking is the point where low-temperature heat recovery is the most accessible given the laws that govern energy degradation in installations handling large quantities of material of poor thermal conductivity. Let us recall that the time required for heat transfer depends on both material conductivity and temperature difference between the hot source and the cold source. From a thermal fluid whose temperature is close to $100{ }^{\circ} \mathrm{C}$, it is not possible,

Table 3. Steam table.

\begin{tabular}{|c|c|c|c|c|}
\hline $\begin{array}{l}\text { Pressure } \\
\text { (bars) }\end{array}$ & $\begin{array}{l}\text { Temperature } \\
\text { ( } \mathrm{C})\end{array}$ & $\begin{array}{l}\text { Latent heat of } \\
\text { vaporization }\left(\mathbf{k J} . \mathrm{kg}^{-1}\right)\end{array}$ & $\begin{array}{l}\text { Liquid water } \\
\text { enthalpy }\left(\mathbf{k J} . \mathrm{kg}^{-1}\right)\end{array}$ & 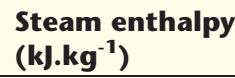 \\
\hline 10 & 184 & 1999 & 781 & 2780 \\
\hline 6 & 165 & 2065 & 703 & 2762 \\
\hline 3 & 144 & 2133 & 605 & 2738 \\
\hline $0=$ ambient & 100 & 2258 & 417 & 2675 \\
\hline
\end{tabular}


unless multiplying the duration of the exchange, to warm up seeds at temperatures well above $60{ }^{\circ} \mathrm{C}$. The constraint of low temperature difference requires increasing the exchange surface or mixing speed.

\section{SOLEX technology: an innovative solution to improve the efficiency of heat recovery}

Solex Thermal Science is a Canadian company founded in 1999 previously under the name Bulkflow Technologies. It has acquired a technology developed in the 80 s to cool fertilizers (Mueller, 1992). The technology was subsequently improved and adapted for heating, cooling and drying bulk solids (Anonymous, 2008). The design of the Solex heat exchanger is based on a bank of vertical heating plates closely spaced to allow a downward flow of bulk material. The granular solid slides down against the plates within which a thermal fluid flows. The exchange takes place by conduction. On some models, drying is also possible by injecting air and extracting it at low speed between the plates. The shape of the plates allows to some extent to renew the layer of seeds in contact with the metal wall which promotes temperature uniformity. With systems sized to large capacity of modern mills $\left(80 \mathrm{t} . \mathrm{h}^{-1}\right)$, several banks of plates are stacked which improves the homogeneity of outlet temperature. Applications are designed using thermal modeling software, which provides accurate product temperatures prediction, to obtain a guaranteed thermal performance (Forniciov, 2008).

The extraction system is adapted to allow a smooth flow avoiding preferential paths. In the case of oilseeds, in contrast to figure 4 , the system is generally constituted by a screw whose core has a diameter decreasing for generating a constant volume in all areas of the device (Farr and Skold, 2012). Available exchange surface is much greater than in a traditional conditioner that allows the use of lower temperature thermal fluids while occupying a small volume. For conditioning grain before flaking, a capacity of $80 \mathrm{t} / \mathrm{h}$ requires a heating power of about $1600 \mathrm{~kW}$. With a conventional vertical conditioner having superimposed plates of $4 \mathrm{~m}$ diameter, it takes about 12 stages to ensure the transfer of heat (personal valuation evaluation).

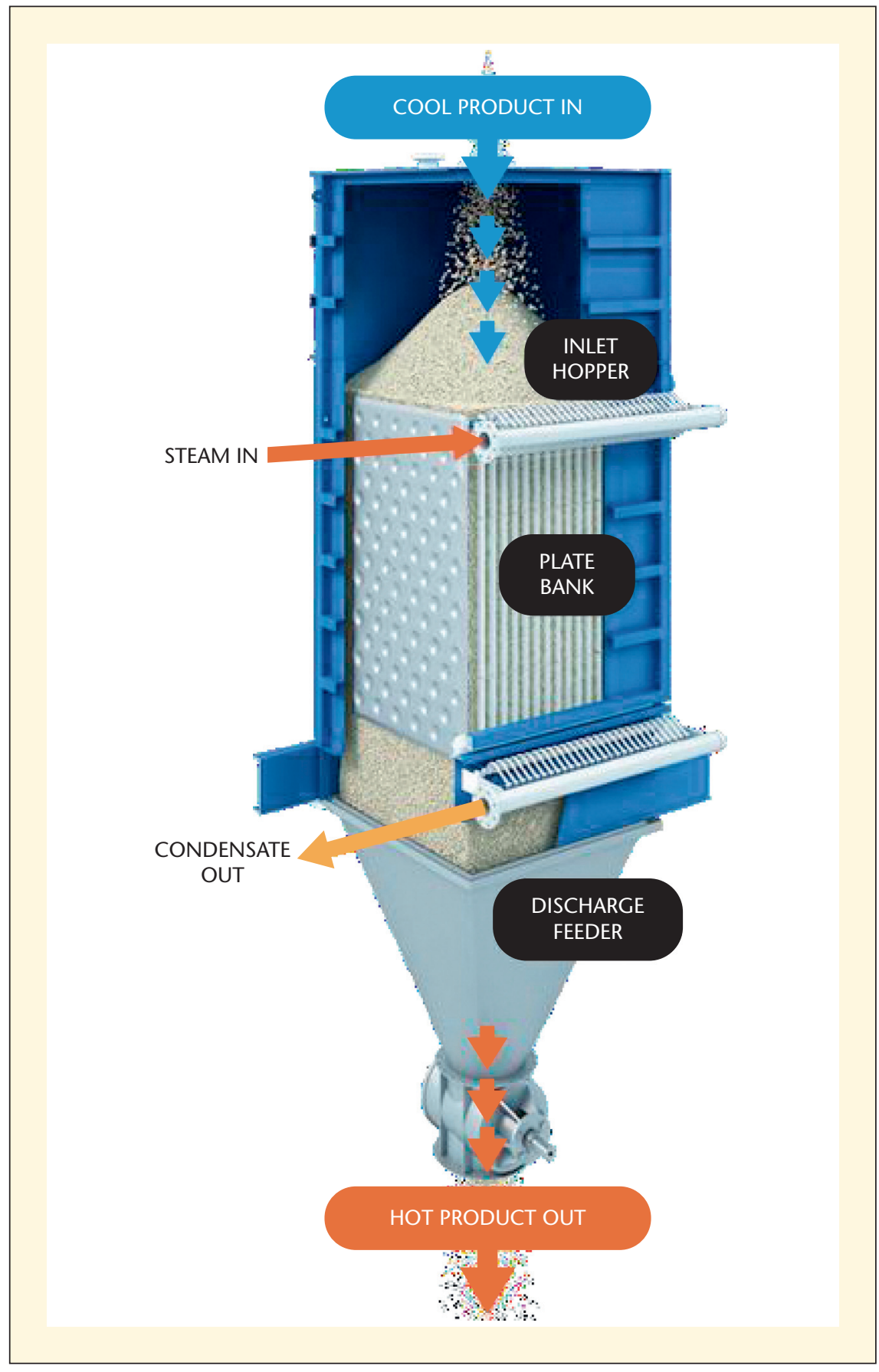

Figure 4. General presentation of the Solex heat exchanger (Solex Cie, 2012).

Assuming that each stage has height of $0.7 \mathrm{~m}$, the occupied volume is in the order of $100 \mathrm{~m}^{3}$. In a Solex exchanger, the power per unit of heating surface is strongly reduced because of the low-temperatures, but the possibility of accommodating a large number of plates per unit of volume allows making the heating in a volume of the order of $50 \mathrm{~m}^{3}$ and a floor area excluding acces- sories of $5 \mathrm{~m}^{2}$. Implementation of Solex exchangers in existing units is facilitated by this compactness.

Another advantage is the lack of mechanical mixing of seeds. Conventional systems are equipped with arms forcing the movement of seeds to bring them into contact with hot surfaces. In vertical conditioners, there is a central shaft on 
which arms are welded which scrape the surface of the plates. Mechanically moving parts are a cause of inflated investment and electricity consumption.

The residence time in the apparatus for a preheating configuration is less than 20 minutes; the temperature of hot water required may be in the range 70 and $98{ }^{\circ} \mathrm{C}$. For lower values, an increase in the heating surface is necessary. In terms of maintenance, the lack of moving parts reduces the frequency and the number of interventions.

These heat exchangers are very well suited to low-temperature heat recovery in plants crushing rapeseed. The theoretical amount of available condensates is not sufficient to supply the heat required, therefore, it is necessary to use extra steam to reach the desired temperature at flakers entry.

\section{Potential advantage of the method for further energy saving}

The ultimate means of heat recovery would be to use the waste heat to dry the grain mass. Conventional dryers are not very effective in evaporating water when the seed is already relatively dry. To understand the superiority of the Solex system over conventional dryers in the case of seeds at low water content, we must return to the principles of drying. In conventional dryers, the enthalpy of the air is given at the inlet heater and then this enthalpy will allow exchanging temperature against water vapor so that the exhausted air leaves the dryer close to the dew point temperature. In the case of relatively dry seeds, it becomes difficult to reach the point of saturation because the seeds are cooled by water evaporation when high temperatures are required to reach the high water activity necessary to saturate the drying air. In consequence, large amounts of heat are wasted to heat air that leaves the dryer far from being saturated. In the Solex heat exchanger, one does not heat the drying air but the solid material. By warming the solid before the air, the water activity rises first facilitating the water transfer. Moreover, the air temperature can be raised while its moisture content grows allowing increasing water load by unit of air mass. For this reason, the mass of air required to dry the seeds is significantly reduced.

For example, dry rapeseed from 8 to $5 \%$, is equivalent to extracting $3.15 \mathrm{~kg}$ of water per $100 \mathrm{~kg}$ of seeds. With a conventional dryer using air at $20^{\circ} \mathrm{C}$ and $70 \%$ of relative humidity, heating this air up to $65{ }^{\circ} \mathrm{C}$ and leaving it at $80 \%$ of relative humidity, there is the possibility of carrying $12 \mathrm{~g}$ of water per $\mathrm{kg}$ of air for an energy cost of $45 \mathrm{~kJ}$. Therefore one must spend $11.7 \mathrm{MJ}$ to dry $100 \mathrm{~kg}$ of seeds. In the system where the grain is warmed by conduction at $80{ }^{\circ} \mathrm{C}$, if the air leaves at $70{ }^{\circ} \mathrm{C}$ with a relative humidity of $70 \%$, one $\mathrm{kg}$ of air can carry $170 \mathrm{~g}$ of water. The energy cost per $\mathrm{kg}$ of air is $420 \mathrm{~kJ} . \mathrm{kg}^{-1}$, thus the expense per $100 \mathrm{~kg}$ of seeds is $7.8 \mathrm{MJ}$. The difference in energy cost is not huge but the heat used could come, at least partially from lowtemperature thermal fluid.

The problem for applying this heat recovery is that drying seeds before flaking would result in dusty flakes and poorly efficient downstream cooking and expelling. In the normal process, the temperature rises when the seeds are still wet and drying occurs only in the lower stages of the cooker. In consequence, the flakes are encountering wet heat during the process which is more efficient to coagulate the proteins. If the seeds were just heated after drying, it is possible that oil extractibility remains low.

In our experience, tests carried out in CREOL pilot plant showed that the flakes cooked using the standard protocol after drying were not suitable for the mechanical extraction. We performed additional experiments to determine what would be the most favorable technical route for the treatment of pre-dried seeds. The best results were obtained by introducing into the press seeds heated to $80^{\circ} \mathrm{C}$ without flaking. According to this work, energy consumption of the press remained close to that of the reference having undergone classical conditioning and cakes pressure obtained in this way had better extractability (residual oil in the cake $1.7 \%$ vs $2.6 \%$ ). In accordance with the objectives of this study, the desolventization of the meal was easier in the case of pre-dried seeds resulting in meals with higher protein solubility (Quinsac, et al., 2011). The possibility of removing the flaking step would simplify the technical route, saving investment, maintenance and energy. This promising work has not been confirmed yet.

Considering that this new processing scheme could be implemented by use of
Solex heat exchanger using low-temperature thermal fluids to heat the seeds up to $80^{\circ} \mathrm{C}$ and evaporating around 30 $\mathrm{kg}$ of water per ton of seeds, the need of heat per ton of seeds would be in order of $200 \mathrm{MJ}$. On the supply side, the condensates would be sharply reduced with the elimination of the cooker and no more than $10 \mathrm{MJ} . \mathrm{t}^{-1}$ would be available. The heat from the evaporated water would be difficult to recover so it was not taken in account. The temperature of the cake could also be reduced, resulting in lower amount of heat to recover (18 MJ.t $\mathrm{t}^{-1}$ of seeds). The other streams are not modified, so the available heat for re-use is now: $150 \mathrm{MJ}$. The residual need of heat becomes $50 \mathrm{MJ} . \mathrm{t}^{-1}$, i.e. $25 \mathrm{~kg} . \mathrm{t}^{-1}$ of steam.

Finally, from $126 \mathrm{~kg}$ of steam per ton of seed, the need for preparation before pressing could fall by about $100 \mathrm{~kg}$. Overall consumption of crushing unit could go from 264 to $160 \mathrm{~kg}$ of steam per ton of grain: a saving of $38 \%$.

\section{Conclusion}

Solex exchangers currently used to preheat seeds before flaking make theoretical possible reductions in energy consumption equivalent to $30-40 \mathrm{~kg}$ of steam per ton of crushed seed but there are not enough steam condensates available to perform that saving and the real figure is below $10 \%$ of the steam consumption. In addition to this interest, using these new exchangers can gain significant place in the environment of older plants where space is limited and they have reduced power needs compared to old conditioners. Another advantage is to use a low temperature thermal fluid which prevents overheating of seed in case of downstream problems which immobilizes the seeds in the exchanger. The main concern is relative to flow problems that could occur in the presence of impurities or large sticky residue accumulation in some areas. According to Solex, these problems are very rare and can be prevented by seeds presorting.

These heat exchangers have a potential to recover heat from cooling cake and meal. In combination with preparation without flaking it would be possible to increase the energy gain by reusing the low-temperature heat to dry the seeds and warm up the seeds. The condition 
to validate such a new processing is to complete the demonstration of the feasibility of pre-pressing without flaking warm and dry seeds as it has been done in the pilot plant of CREOL. Besides the energy saving of $38 \%$ mentioned, such an achievement would reduce odor emissions during cooking and reduce costs by eliminating the flaking and reducing the number of conveyors.

Conflicts of interests: The author has no interests in Solex thermal Science and this article is not sponsored by the said company.

\section{REFERENCES}

Alam, Shove. Simulation of soybean drying. Transactions of the ASAE 1973; 16: 134-6.

Anderson G. Oilseed extraction and meal processing. In: Proceedings of the world congress on vegetable proteins utilization in human foods and animal feedstuffs. The American Oil Chemists Society ed. Champains, USA: The American Oil Chemists Society, 1989.

Anonyme. Bulkflow Technologies changes name to Solex Thermal Science. 2008 [Online] Available at: http://www.chemicalprocessing. com/industrynews/2008/008.html [Accessed 1209 2012].

Aviara NA, et al. Effect of moisture content and temperature on the specific heat of soybean, Moringa oleifera seed and Mucus flagellipes nut. International Journal of Agricultural \& Biological Engineering 2011; 4: 1-6.
Baümeler ER, Crapiste GH, Carelli AA. Solvent extraction: kinetic study of major and minor compounds. I Am Oil Chem Soc 2010; 87: 1489-95.

Berthon G. Chaleur spécifique du soja. Informations Techniques CETIOM 1977; 59: 3-7.

Deshpande S, Satish B. Specific heat of Soybean. J Food Process Engin 1999; 22: 469-77.

Farr WE, Skold F. Drying and cooling collets from expanders with major energy saving. In: Green vegetable oil processing. Urbana, IL, 61802: AOCS Press, 2012.

Forniciov CE. Interview de Claudio E. Forniciov après le changement de nom de la société. 2008 [Online] Available at: http://www. provrac.com/interview-express.html?tx ttnews\%5Btt_news\%5D=64\&tx_ttnews\% 5 BbackPid $\% 5 \mathrm{D}=69 \& \mathrm{cHash}=78289 \mathrm{c} 17 \mathrm{cb}$ [Accessed 1209 2012].

Garnon. Qualité des graines de tcolza-Récolte 2011. 2011 [Online] Available at: http:// www.cetiom.fr/uploads/tx_cetiomlists/QUAL GRAINES_CO_11_BD.pdf [Accessed 1608 2012].

llori T, Oradugba O, Raji A. Physical properties of mexican sunflower seed. International Agrophysics 2011; 25: 299-302.

Joly F. Constantes physiques et thermophysiques des corps gras. Paris: ITERG, 1982.

Kocabiyik H, Tezer D. Determination of thermal properties of rapeseed. Journal of Tekirdag Agricultural Faculty 2007; 4: 65-70.

Laisney J. L'Huilerie Moderne. Paris: Compagnie Française pour le Développement des Fibres Textiles CFDT, 1984.
Linde DR. Handbook of chemistry and Physics. Boca Raton: CRC Press (USA), 2009.

Moysey E, Shaw J, Lampman W. The effect of temperature and moisture on the thermal properties of rapeseed. Transaction of the ASAE 1977; 20: 769-71.

Mueller MM. Method and appartus for cooling particulate solids. US, Patent No. 5,167,274, 1992.

Muir W, Sinha R. Theoretical rates of flow of air at near-ambiant conditions required to dry rapeseed. Canadian Agricultural Engineering 1986; 28: 45-9.

Peyronnet C, Dauguet, S. Qualité des tourteaux de colza 2011. 2012 [Online] Available at: http://www.cetiom.fr/uploads/tx_cetiomlists/tourteaux_CO2011_BD.pdf [Accessed 1608 2012].

Quinsac A, Carré P, Loison JP. Effects of seeds drying prior the rapeseed crushing process. Potential benfits for energy consummption, meal quality and solvent emission. Prague: GCIRC, 2011.

Schumacher $\mathrm{H}$. Ultimate energy possibilities in conventional solvent extraction. / Am Oil Chem Soc 1983; 60: 417-8.

Solex Cie. About the company. 2012 [Online] Available at: http://www.solexthermal. com/about [Accessed 1209 2012].

Srours S. Propriétés thermiques des grains production de chaleur et de CO2. In: Conservation et stockage des grains et graines et produits dérivés. Paris: Lavoisier Tec \& Doc, 1982.

Timbers G. Properties of rapeseed: 1. Thermal conductivity and specific heat. Canadian Agricultural Engineering 1975; 17: 81-4. 